\title{
Prostorska razpršenost stanovanjskih enot kot pomemben dejavnik vpliva na stroške dolgotrajne oskrbe
}

Več kot $90 \%$ starostnikov bi se rado postaralo tam, kjer živijo. To idejo podpirajo tudi strateški načrti Evropskega semestra za dolgotrajno oskrbo (ang. European semesters on long-term care) za države članice, vendar ne vključujejo dovolj inovacij, da bi resnično izboljšali življenjske razmere starejših $\mathrm{z}$ ustrezno opremljenim okoljem in vzdržnim financiranjem. Prostorsko razpršenost stanovanj in gostoto poselitve $\mathrm{v}$ funkcionalnem območju bi morala pri načrtovanju grajenega okolja in drugih objektov za starejše posebej upoštevati vodstva ustanov, ki starejšim zagotavljajo namestitev, zdravstveno oskrbo in druge storitve, saj so cene logistike (prevoz materiala, delovna sila, prevoz starostnikov $\mathrm{v}$ dnevne programe itd.) precej odvisne od teh dveh dejavnikov. Na podlagi podatkov doma za ostarele v eni od madžarskih občin smo ocenili in optimizirali načrtovanje poti ter razporejanje za potrebe oskrbe starostnikov na domu glede na različne možne prostorske razporeditve in z različno gostoto strank. Poti negovalnega osebja, ki oskrbuje starostnike, smo simulirali s problemom trgovskega potnika (ang. multiple travelling salesman, $m T S P$ ), rešitve pa navajajo potrebno delovno silo in časovne zahteve za opravljanje storitev. Orodje, ki nam je omogočilo proučiti izide različnih možnosti, bi lahko tudi stroki pomagalo pri predvidevanju in načrtovanju prihodnjih sprememb pri stroških dolgotrajne oskrbe zaradi vse večjega števila starejših, ki bodo pri ohranjanju samostojnosti potrebovali pomoč, spreminjata pa se tudi gostota in razpršenost gospodinjstev.

Ključne besede: stanovanja, dolgotrajna oskrba, načrtovanje storitev, prostorska razpršsenost, funkcionalna regija 


\section{Uvod}

Študije o dolgotrajni oskrbi kažejo, da želijo starostniki v primerjavi z drugimi možnostmi namestitve pogosto ostati v lastnih domovih (Keenan, 2010; Gillsjö idr., 2011). Kot kažejo novejše študije iz Slovenije, bi se več kot $90 \%$ oseb, starih nad 65 let, rado staralo tam, kjer so, torej v trenutnem bivališču oziroma v bivališču, ki bi si ga izbrali, dokler je mogoče (Kavšek in Bogataj, 2015, 2016). To lahko omogočijo tudi nove oziroma komunikacijske tehnologije, ki v zdravstveno oskrbo, velnes ter varno in varovano okolje prinašajo najpomembnejše inovacije. Nove tehnologije v oskrbi, kot so prenosni telefoni, spletne strani in tablice, pomagajo negovalcem starejših doseči učinkovitejše opravljanje storitev. Evropski semester (na primer za Slovenijo: Priporočilo Sveta v zvezi z nacionalnim programom reform Slovenije za leto 2014 in mnenje Sveta o programu Slovenije za stabilnost za leto 2014; Svet Evropske unije, 2014) podpira njihovo uvedbo tudi v zdravstvenem in oskrbovalnem sektorju. Trenutno obstaja le nekaj načrtov za izboljšanje namestitev, ki podpirajo ta cilj. Spodbujanje uvajanja inovacij bi omogočilo premik od institucionalizirane $k$ domači oskrbi v ustrezno zasnovanih stanovanjskih enotah. Življenjske razmere starejših je treba izboljšati v ustrezno opremljenih okoljih $s$ trajnostnim financiranjem. Prostorska razpršitev stanovanj mora biti upoštevana zlasti pri načrtovanju grajenega okolja in ustanov za starejše, saj se logistični stroški sorazmerno povečujejo z razpršenostjo stanovanj, kjer se storitve izvajajo. Vodstva ustanov za starejše in zdravstvene ustanove, ki ponujajo namestitev, zdravstveno oskrbo in druge storitve za starejše, bi morali upoštevati stroške transporta materiala, zaposlitve medicinskih sester in drugih uslužbencev ter transport starejših na dnevne aktivnosti, odvisne od razporeditve stanovanjskih enot. Dnevna oskrba na domu je namreč zahtevna s stališča dela in zaposlenih, zato je preudarno načrtovanje poti in urnikov ključno za sprejemljivo razmerje med logističnimi stroški in kakovostno oskrbo ter zadovoljstvom starejših.

V primerjavi z drugimi aktualnimi izzivi sodobne družbe, kot so klimatske spremembe in finančne krize, lahko staranje dokaj natančno napovemo in predvidimo tudi njegove posledice. Oblikovalci politik se zato lahko pripravijo na spremembe v demografski strukturi (OECD, 2015). V poročilu o staranju v mestih je navedeno: »Boljši pristopi k urbanistični politiki nam bodo pomagali izboljšati kvaliteto življenja prebivalcev vseh starosti (OECD, 2015: 18). Da bi to omogočili, so začrtali strategije, ki naj bi učinkovito blažile tveganja in pripomogle $\mathrm{k}$ temu, da bi se čim bolj izrabile priložnosti. Ključne strategije in podstrategije, razčlenjene do natančnejših pristopov, povzema preglednica 1 .
Menimo, da nekatere podstrategije ključnih strategij 5 in 6, kot so »Spodbujati cenovno dostopna stanovanja $\mathrm{z}$ inovativnimi shemami za zagotavljanje socialnih stanovanj, Spodbujati storitve oskrbe na domu, Ponovno določiti primerne lokacije za urbano infrastrukturo z optimizacijo uporabe zemljiščc, Uvesti orodja za učinkovite javne naložbe «(OECD, 2015: 65), zahtevajo celovit pristop $\mathrm{k}$ načrtovanju in razvoju. $\mathrm{V}$ tem članku želimo osvetliti razmerje med ponudbo stanovanj in nego na domu ter predvideti dejavnike, ki vplivajo na ceno nege na domu. Zaradi staranja prebivalstva se bo potreba po dolgotrajni oskrbi in dostopnih stanovanjih za starejše bistveno povečala. Neodvisno bivanje starejših v lastnih domovih bo zahtevalo ustrezno zgrajeno in dostopno okolje. Trenutne stanovanjske enote bodo težko sledile potrebam. Po podatkih Poročila EK in partnerjev (Evropska komisija, 2015b) je 70 do 80 \% bivališč v Veliki Britaniji in 90 \% v Nemčiji neprimernih za neodvisno življenje starejših, saj so težko dostopna za osebe s funkcionalnimi oviranostmi in kroničnimi stanji ter niso opremljena $s$ potrebno digitalno infrastrukturo za povezano nego. Poročilo tudi navaja, da v Nemčiji že zdaj potreba po starostnikom prijaznih bivališčih presega razpoložljivosti za 2,5 milijona. $\mathrm{Na}$ Nizozemskem ocenjujejo, da bi bilo treba 330.000 bivališč prilagoditi v starostnikom prijazna bivališča. Za Vzhodno Evropo je manj podatkov. Na Madžarskem ni posebne politike, ki bi se ukvarjala $\mathrm{z}$ demografskimi spremembami, niti z ustvarjanjem integriranega sistema dolgotrajne oskrbe ali starostnikom prijaznim načrtovanjem urbanega prostora. Ponudba socialnih stanovanj je majhna. Od približno 35 tisoč bivalnih enot (Centralna madžarska statistična pisarna, 2016) je le omejeno število namenjenih upokojenim, ki potrebujejo nego na domu. Ocenjujejo, da je število teh enot 5.000 (Csehák, 2003). Potreba za namestitve z nego se s staranjem populacije stalno povečuje, tako v lastnih domovih starostnikov, kot $\mathrm{v}$ domovih za starejše. $\mathrm{Na}$ čakalnih seznamih za domove starejših je v povprečju 160 do170 starostnikov, ki si želijo bivati v domu v njihovem okraju. Do vselitve tistih, ki izpolnjujejo pogoje, pa lahko mine od 1,5 leta do 2 leti (Rosta, 2014). Starejšim na čakalnih seznamih pomagajo s storitvami nege na domu ali neformalno nego, to pa glede na trenutne trende staranja populacije ni optimalno ali dolgoročno vzdržno. Ko bodo lokalne oblasti pred dilemo, ali naj gradijo bolj ali manj razpršene stanovanjske enote v tako imenovanih upokojitvenih vaseh, namestitve za starostnike v urbanih okoljih ali zagotovijo nego na domu, bodo morale primerjati stroške gradnje nepremičnin s stroški zagotavljanja ustreznih storitev, vštevši naložbe v dnevno logistiko in dostopno urbano okolje.

V predhodni študiji (Szander idr., 2016) smo proučevali časovno načrtovanje nege na domu na enakem funkcionalnem območju z različnih vidikov. Območje Zalaegerszega obsega $99,98 \mathrm{~km}^{2}$. Tu živi 67 starostnikov, ki potrebujejo nego na domu, torej 0,67 stanovanjske enote $/ \mathrm{km}^{2}$. Podatke o lokaciji 
Preglednica 1: Predlagane ključne strategije in podstrategije za staranje v mestih

\begin{tabular}{|c|c|}
\hline Ključne strategije & Podstrategije \\
\hline \multirow{2}{*}{ 1. razvoj dolgoročne vizije } & $\begin{array}{l}\text { Mesta v različnih fazah demografske tranzicije lahko razvijejo vizijo za svojo prihodnost z osredoto- } \\
\text { čanjem na najbolj kritične izzive, s katerimi se srečujejo. }\end{array}$ \\
\hline & Te vizije naj vključujejo kvantitativne ocene z uporabo mednarodno primerljivih kazalnikov. \\
\hline \multirow{2}{*}{ 2. razvoj kazalnikov } & $\begin{array}{l}\text { Razviti kazalnike za promet, zdravje in socialno varstvo, urbani razvoj, delo, stanovanjsko politiko in } \\
\text { okolje ter civilnodružbeni sektor. }\end{array}$ \\
\hline & $\begin{array}{l}\text { Mesta izberejo najboljšo kombinacija kazalnikov glede na fazo in demografske procese, ki jim ustre- } \\
\text { zajo. }\end{array}$ \\
\hline \multirow{2}{*}{$\begin{array}{l}\text { 3. promocija zdravja za vse gene- } \\
\text { racije }\end{array}$} & Promovirati zdravje z uporabo informacijske tehnologije. \\
\hline & Spodbujati hojo kot preventivno dejavnost za izboljšanje zdravja. \\
\hline
\end{tabular}

Mestne uprave lahko postanejo model oziroma zgled za dodatno usposabljanje starejših zaposlenih.

4. večja vključenost starejših $v \operatorname{trg}$ dela in socialne aktivnosti

Olajšati dostop do služb s širjenjem mreže javnega prevoza.

Spodbujati podjetnost v starejših starostnih skupinah.

Spodbujati starejše k prostovoljnemu delu v njihovih skupnostih.

Razvijati aktivnosti, ki združujejo starejše in mlajše.

Spodbujati cenovno dostopna stanovanja z inovativnimi shemami za zagotavljanje socialnih stanovanj, skupaj z javno-zasebnimi partnerstvi in povečanjem ponudbe manjših bivalnih enot.

5. dostopna stanovanja $v$ dostopnih okoljih

Izboljšati dostop do zaposlitve ter javnih in zasebnih storitev z javnim transportom.

Spodbujati storitve oskrbe na domu.

Ponovno določiti primerne lokacije za urbano infrastrukturo $z$ optimizacijo uporabe zemljišč.

6. znova oblikovati urbana območja Vlagati v izboljšanje izkušnje pešcev v urbanih območjih.

ter povečati njihovo privlačnost in udobje za prebivalce

Vključiti strategije za spodbujanje socialne in ekonomske trajnosti mest v različne politike.

Uvesti orodja za učinkovite javne naložbe.

Vir: OECD (2015)

starostnikov in njihovih potrebah po negi nam je dal Center za dolgotrajno oskrbo v Zalaegerszegu (ang. Long-term care centre of Zalaegerszeg, CCE). Namen študije je bil izmeriti vpliv izboljšanja kakovosti storitev $\mathrm{z}$ določitvijo točnega termina, ko starostnika obišče oskrbnik, namesto da bi moral ta čakati nanj brez informacij. Posledica neusklajenega prihoda s širše določenimi termini obiskov sta več neizrabljenega časa v delovnem času oskrbnikov in potreba po večjem številu oskrbnikov. Pomembne so tudi razlike v delovnih nalogah (čas nege, ki jo opravi vsak oskrbnik) glede na metode dodeljevanja starostnikov oskrbnikom. Glede na prejšnje rezultate smo izboljšali model: dodeljevanje starostnikov oskrbnikom smo dodali kot spremenljivko, tako da je število oskrbnikov postalo del optimizacijskega procesa (zmanjšanje).

\section{Metodologija}

Gostota povpraševanja in razpršenost strank v funkcionalni regiji - informacije o razpršenosti strank in razdaljah med njimi v funkcionalnem območju - nam omogoča ocenjevanje vpliva teh dveh parametrov na ceno storitev. $\mathrm{Na}$ funkcionalnem območju občine mora biti oskrba starejših na domu zagotovljena povsod, tudi na obrobju mest. Izhodišče za razvoj distribucije je gostota populacije funkcionalnega območja in delež tistih, ki potrebujejo storitve. Gostota populacije je razmerje med povprečno letno populacijo in velikostjo funkcionalnega območja, brez upoštevanja kopenskih voda (Statistični urad pri Evropski komisiji, 2016). Na splošno pomeni velika gostota nižje stroške oskrbe, saj je na danem območju več strank. Profil uporabnikov dolgotrajne oskrbe kaže precej homogeno skupino. Njihove potrebe izvirajo iz njihovega zdravstvenega stanja ter zmožnosti za dnevna opravila (ang. Activities of daily living, $A D L$ ) in podporna dnevna opravila (ang. Instrumental Activities of daily living, IADL). Homogenost omogoča, da dovolj natančno predvidimo pričakovano število prejemnikov dolgotrajne oskrbe (Czibere in Gál, 2010). Ker so cene logistike in distribucije zelo odvisne od variance razdalj med strankami, je treba razpršenost teh razdalj upoštevati tudi pri načrtovanju. Razpršenost pomeni, kako so točke razporejene na danem območju. To merimo $z$ varianco ali standardno deviacijo opazovanih razdalj (Briggs, 2010). Z vidika logistike je optimalna razpršenost $\mathrm{z}$ majhno standardno deviacijo razdalj (Chopra, 2003). 


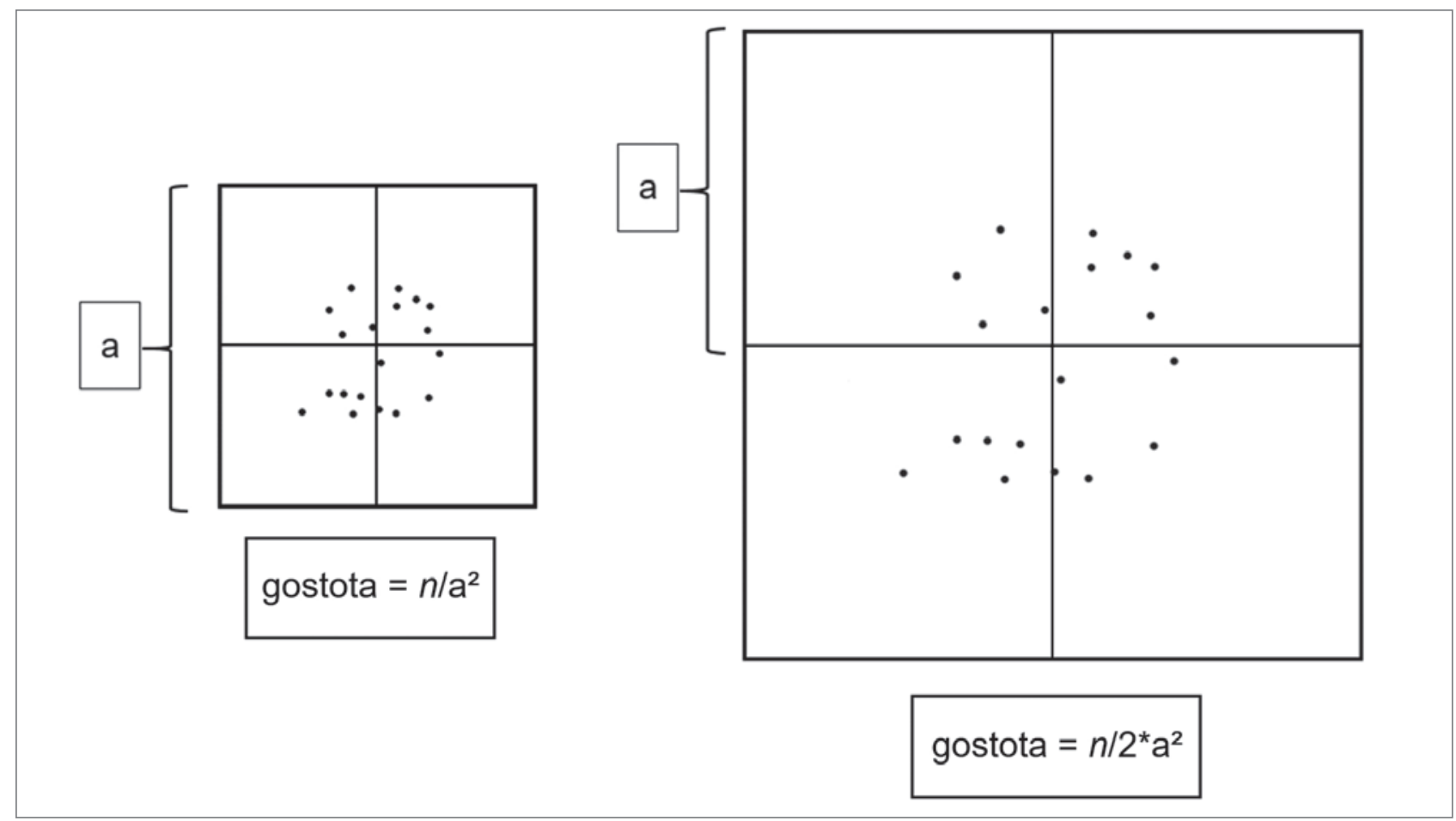

Slika 1: Spreminjanje gostote s spreminjanjem velikosti območja, kjer ponujajo storitve

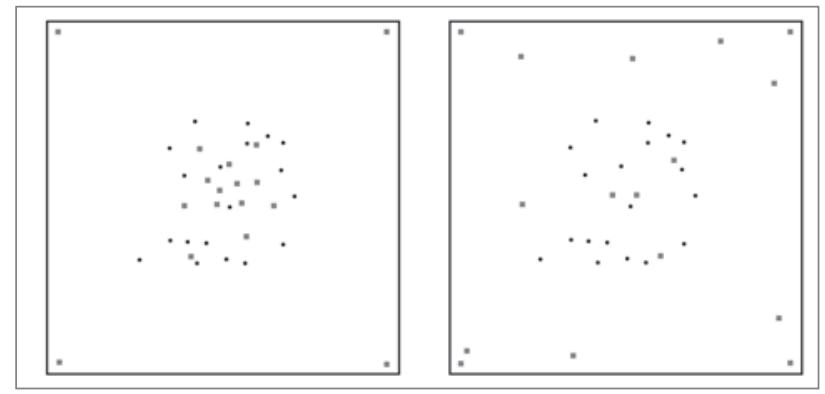

Slika 2: Povečevanje zahtev z manjšo (levo) in večjo (desno) standardno deviacijo razdalj

Pri načrtovanju storitev za starejše je treba upoštevati, da staranje ne poteka enako $\mathrm{v}$ vseh regijah, ter da lahko pričakovano število uporabnikov storitev dolgotrajne oskrbe napovemo $\mathrm{z}$ indeksom staranja in demografskih podatkov. Toda ta poenostavitev ne da dovolj podatkov v prostorskem smislu. V urbanih naseljih je namreč lahko število starejših sorazmerno višje, denimo starejši v mestnih središčih, ki jih mladi zapuščajo zaradi suburbanizacije velikih mest (Kučera in Burcin, 2010). $\mathrm{V}$ drugih primerih je lahko delež starostnikov merljivo višji v manj razvitih perifernih območjih kot $\mathrm{v}$ novejših in naprednejših predmestjih. To je posledica socialne neenakosti (Szirmai idr., 2010). V nekaterih državah so raziskovalci ugotovili tako imenovane naravno pojarljajoče se upokojitvene skupnosti (ang. Naturally occurring retirement communities, NORC), znane tudi kot ruralne destinacije za migracije starejših (ang. Rural destinations of older migration, RDOMs), »namerno naseljene, a nenačrtovane namestitve za starejše « (Golant, 2002: 67). Verjetnost povečanja potreb po dolgotrajni oskrbi je v takšnih okoljih veliko večja, kot bi lahko predvidevali na podlagi povprečne starosti populacije na določenem območju. Ko načrtovanje storitev temelji na gostoti strank na določenem območju (število starostnikov $/ \mathrm{km}^{2}$ ), sprememba enega kazalnika vpliva tudi na drugega. $V$ preglednici 1 je prikazano, kaj se zgodi, če so storitve načrtovane na večjem območju, število strank in vzorec lokacije pa ostaneta enaka. Razdalja med točkami se spreminja sorazmerno $\mathrm{z}$ gostoto populacije in lahko sklepamo, da se bo s spremembo velikosti območja spremenila tudi povprečna razdalja med točkami.

Raznolikost strukture in oblike naselij zahteva globlje razumevanje različnih prostorskih vzorcev in gostote zahtev. $\mathrm{Na}$ sliki 2 sta predstavljena dva primera, ko se zahteve po negi na domu povečujejo enako v absolutnih številkah (sivi kvadratki), njihove lokacije pa sledijo dvema različnima zasnovama, zato bi potrebovali različni razporeditvi virov. $\mathrm{Da}$ bi proučili vpliv spremembe zasnove ali števila starostnikov, smo zasnovali dva »scenarija « načrtovanja. V scenariju 1 se predvideva naključna razporeditev starostnikov, potrebnih nege na domu, večinoma $\mathrm{v}$ večstanovanjskih stavbah. V scenariju 2 pa imamo isto mesto $\mathrm{z}$ enako gostoto starostnikov (število $/ \mathrm{km}^{2}$ ), toda bolj razpršene stanovanjske enote, torej je standardna deviacija razdalj večja. Na scenarija lahko pogledamo še drugače: ohranimo vrednost disperzije in jo združimo z različnimi vrednostmi gostote (preglednica 2). 
Preglednica 2: Scenariji načrtovanja za različno razporeditev namestitev in število starostnikov

\begin{tabular}{lll}
\hline Scenarij načrtovanja 1 & Scenarij načrtovanja 1.1 & Scenarij načrtovanja 1.2 \\
\hline večinoma večstanovanjske stavbe & $\begin{array}{l}\text { gostota } A \\
\text { razpršenost B }\end{array}$ & $\begin{array}{l}\text { gostota } D \\
\text { razpršenost B }\end{array}$ \\
\hline Scenarij načrtovanja 2 & Scenarij načrtovanja 2.1 & Scenarij načrtovanja 2.2 \\
\hline večinoma enostanovanjske stavbe & $\begin{array}{l}\text { gostota A } \\
\text { razpršenost } C\end{array}$ & $\begin{array}{l}\text { gostota A } \\
\text { razpršenost B }\end{array}$ \\
\hline
\end{tabular}

Matematična ponazoritev problema: uporabili smo tako imenovani problem trgovskega potnika (ang. multiple travelling salesman problem, mTSP), pri katerem oskrbnik obišče starostnika enkrat po najkrajši možni poti. Matematični model temelji na naših preteklih ugotovitvah (Szander idr., 2016), vendar smo oskrbnike določili z upoštevanjem dejstva, da želi vsak starostnik pomoč oskrbnika, ki ga je vajen, česar v originalnem modelu ni. MTSP-model je bil prilagojen in formaliziran, kot ga je opisal Tolga Bektas (2006). Postopek je bil uporabljen za iskanje najkrajše možne poti za obiskovanje starostnikov. Enačbe od 1 do 3 ponazarjajo razporeditev del, dopolnjeno z eliminacijsko konstanto sub-tour (enačba 4), ki temelji na formuli Miller-Tucker-Zemlin - MTZ (Miller idr., 1960). Številčno programiranje za problem mTSP je opisano $\mathrm{v}$ formulah v nadaljevanju.

Predstavljajmo si graf $G=(A, L)$ s skupino vozlišc $A$, ki pomenijo domove starostnikov, prejemnikov dolgotrajne oskrbe. Poznamo naslove in prostorske koordinate na zemljevidu, L pa je komplet robov, označen na cestah med vsemi mogočimi pari vozlišč, pri katerih so znane minimalne vrednosti časa za pot med njimi. Tako je za vsak par vozlišč najkrajši rob definiran $s$ časom potovanja. Oskrbnik se giblje med domovi starostnikov, pot začenja v občinskem domu za ostarele (center za nego CCE) in se vrača vanj. Njegov delovni čas je sestavljen iz $90 \%$ časa na terenu ter $10 \%$ časa za pripravo in poročila v občinskem domu za ostarele.

Cilj (enačba 1) je čim bolj zmanjšati število oskrbnikov do točke (enačbe 2 do 6), kjer je trajanje poti $c(k)$ enako ali manjšse kot pri 90-odstotni terenski delovni obremenitvi oskrbnikov (8 ur/dan). Pot oskrbnika (k) je seštevek časovnih razdalj med obiskanimi starostniki $\left(c_{i j}\right)$ in predpisanim časom nege $\left(w_{j}\right)$ ter časom za pot od občinskega doma za ostarele in nazaj.

$$
\begin{gathered}
c(k)=\sum_{i=0}^{n}\left(\sum_{i=0}^{n} c_{i j} x_{i j k}+x_{i j k} w_{j k}\right)+c_{i 0 k} x_{i j k} \leq 0,9 * 8 \quad k=1,2 \ldots \mathrm{m} \\
x_{i j k}=0,1 \\
c_{i j}=s_{i j} * d_{i j}
\end{gathered}
$$

Spremenljivka je enaka 1 , če gre $k$-ti oskrbnik nemudoma od $i$ do $j$, in $0 \mathrm{v}$ drugih primerih. $d_{i j}$ je najkrajša razdalja po cestah in $s_{i j}$ je optimalna hitrost, ki jo je mogoče doseči na dani cesti. Oskrbniki začnejo svojo dnevno krožno pot v občinskem domu za ostarele (CCE), označenem $\mathrm{z}$ vozliščem 0 , in se vračajo na isto lokacijo po manj kot 8 urah dela po obisku zadnjega starostnika.

Enačbe 3 in 4 so bile dodane k TSP-formuli, da bi zagotovili, da natančno $m$ oskrbnikov odrine iz CCE-ja in se vrne vanj. Oskrbnik mora zapustiti lokacijo $i$, ko je nega opravljena, in gre na samo eno lokacijo $j$ od vseh preostalih lokacij, kot je navedeno v enačbi 5 .

$$
\sum_{k=1}^{m} \sum_{j=1}^{n} x_{0 j k}=m
$$

$$
\begin{array}{ll}
\sum_{k=1}^{m} \sum_{i=1}^{n} x_{i 0 k}=m & \\
\sum_{j=1}^{n} x_{i j k}=1 \quad \forall i & \forall \mathrm{k} \\
\sum_{i=1}^{n} x_{i j k}=1 \quad \forall j & \forall \mathrm{k}
\end{array}
$$

Po enačbi 6 lahko oskrbnik, če je v danem trenutku na določeni lokaciji, tja pride le z ene od prejšnjih lokacij. Eliminacijska konstanta sub-tour (enačba 7) je ključni del formule TSP. Omogoča, da imamo le eno pot za vsakega oskrbnika, ki pokriva vse lokacije, za katere je odgovoren, namesto dveh ali več posameznih poti, da bi pokrili vse lokacije. Gre za spremenljivke dummy. Te pomenijo sekvenco, ko je lokacija $i$ obiskana, njene vrednosti so arbitrarna realna števila, $p$ pa je maksimalno število vozlišč, ki jih obišče vsak oskrbnik (Bektas, 2006).

$$
\begin{gathered}
u_{\mathrm{i}}-u_{\mathrm{j}}+\mathrm{p} x_{\mathrm{ijk}} \leq \mathrm{p}-1 \quad \mathrm{p} \quad \mathrm{s}=\mathrm{i}, \mathrm{j} \\
x_{i j k}=0,1 \\
i=0 \ldots n-1 \\
j=1 \ldots n \\
\forall \mathrm{k} ; \quad k=1,2, \ldots, m
\end{gathered}
$$




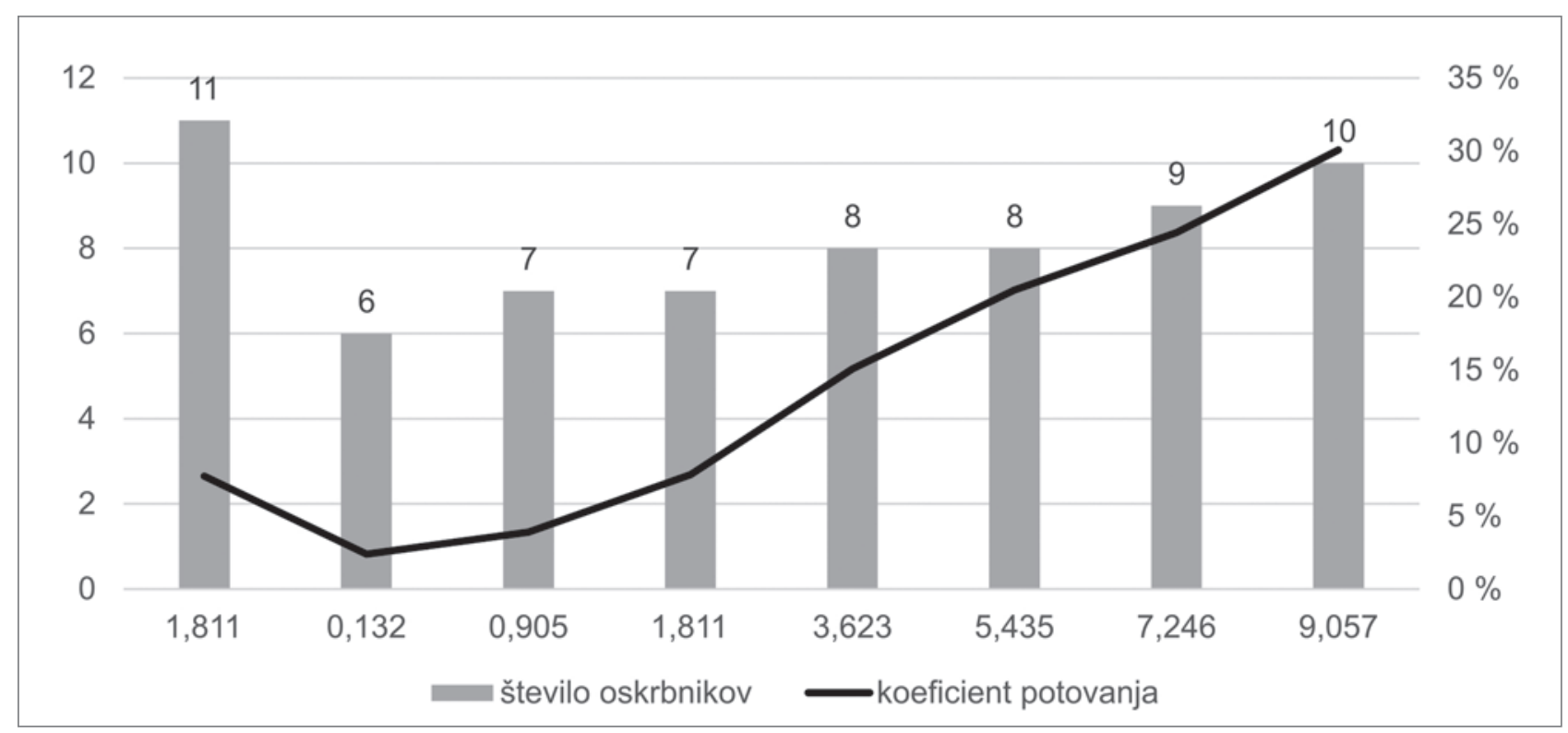

Slika 3: Potrebno število oskrbnikov in razpršenost starostnikov

\section{Izvedba raziskave in rezultati}

Vsak primer (različna gostota in razpršenost) smo optimizirali za najnižje možno število oskrbnikov. Zaradi boljših rezultatov nismo upoštevali načel dodeljevanja starostnikov oskrbnikom. $\mathrm{V}$ izračunih je to pomembna omejitev, saj se starostniki navadijo in navežejo na oskrbnika, zato je bolje, da jih vedno obiskuje isti. Ker se v tej študiji osredotočamo na iskanje najnižjega števila oskrbnikov za uspešno opravljanje nalog, nismo vključili te možnosti. Problem bi lahko preprosto rešili, če bi dodali nekaj obveznih pravil za določanje starostnikov oskrbnikom, toda optimalna vrednost bi bila veliko višja. V nadaljnjih raziskavah bi lahko izračunali, koliko bi bil starostnik pripravljen plačati za to dodatno ugodnost. Izhajali smo iz omejitve 430 minut delovne obremenitve skupaj s časom za pot. To je približno $90 \%$ porabe kapacitet, ostalih $10 \%$ pa je namenjenih nepredvidenim dogodkom. Delovna obremenitev čez teden ni enaka, optimizirali smo najzahtevnejši dan, ko je naročenih največ starostnikov.

Pri simulaciji smo lahko najprej zmanjšali število potrebnih oskrbnikov z 11 na 7 pri prvotni razporeditvi, $\sigma=1,811$, vendar je do tega prišlo zaradi večje hitrosti (oskrbniki potujejo z avtobusom ali hodijo, zato je njihova hitrost manjša) in spremenjene dodelitve oskrbnikov. Rezultati ob drugačni razpršenosti so predstavljeni na sliki 3, prikazan je tudi čas, porabljen za pot kot odstotek delovnega časa. Na sliki 4 pa so prikazane poti 7 oskrbnikov po optimizaciji.

Da bi ustvarili variacije za scenarij načrtovanja 2.1, smo povečali standardno deviacijo časovnih obdobij za pot med vsako točko, da bi ponazorili drugačno razpršenost. $\mathrm{V}$ izračunih to pomeni različne vrednosti v matrici cene kot posledice omejitve (enačba 2). Preglednica 3 prikazuje rezultate in čas, ki smo ga porabili za optimizacijo (v minutah). $V$ prvotnem scenariju je najdaljša razdalja med dvema točkama znašala 8,7 minute, standardna deviacija poti je bila $\sigma=1,8115$, čas poti med najbolj oddaljenima točkama v scenariju z največjo hipotetično razpršenostjo $(\sigma=9,0577)$ pa je bil 43,5 minute. To se nam je zdelo še vedno realno, saj se v srednje velikem mestu vozimo približno 45 minut med njegovima najbolj oddaljenima točkama.

Teoretično lahko $\sigma$ potovalnega časa poti povzroči sprememba hitrosti ali razdalje $\left(c_{i j}=s_{i j}{ }^{*} d_{i j}\right)$, kot je prikazano v matematični formuli. Ker namen tega članka ni, da bi ustvarili pripomoček za odločanje glede transportnih sredstev, je čas poti sestavljen ukrep. Torej opisujemo različne primere, za analizo katerih je uporabljena $\sigma$. Tako je naš model uporaben za izbiro sredstev transporta in odločitve pri lokacijskem načrtovanju. Delež časa, porabljenega za pot, se je glede na skupni čas enakomerno povečeval z zviševanjem $\sigma$. V proučevanih scenarijih je bila najnižja vrednost standardne deviacije $\sigma=0,9057$, ker so lokacije manj razpršene ali se lahko oskrbniki gibljejo z večjo hitrostjo (povprečno $48,85 \mathrm{~km} / \mathrm{h}$ - to je ob gostem prometu večinoma nemogoče), vendar ta scenarij ni zmanjšal števila oskrbnikov. Simulirali smo tudi »ekstremno « situacijo, ko so si lokacije starostnikov tako zelo blizu, da je za pot od enega do drugega starostnika potrebna le ena minuta, in je $\sigma$ ekstremno majhna, $\sigma=0,132$ (to je standardna deviacija med 1 in 0 minut za 55 lokacij starostnikov). Ker je bil čas skupne predpisane nege za proučevane starostnike 2,472 minute, bi lahko s skoraj nično $\sigma$ lokacij znižali potrebno število oskrbnikov na 6 . 


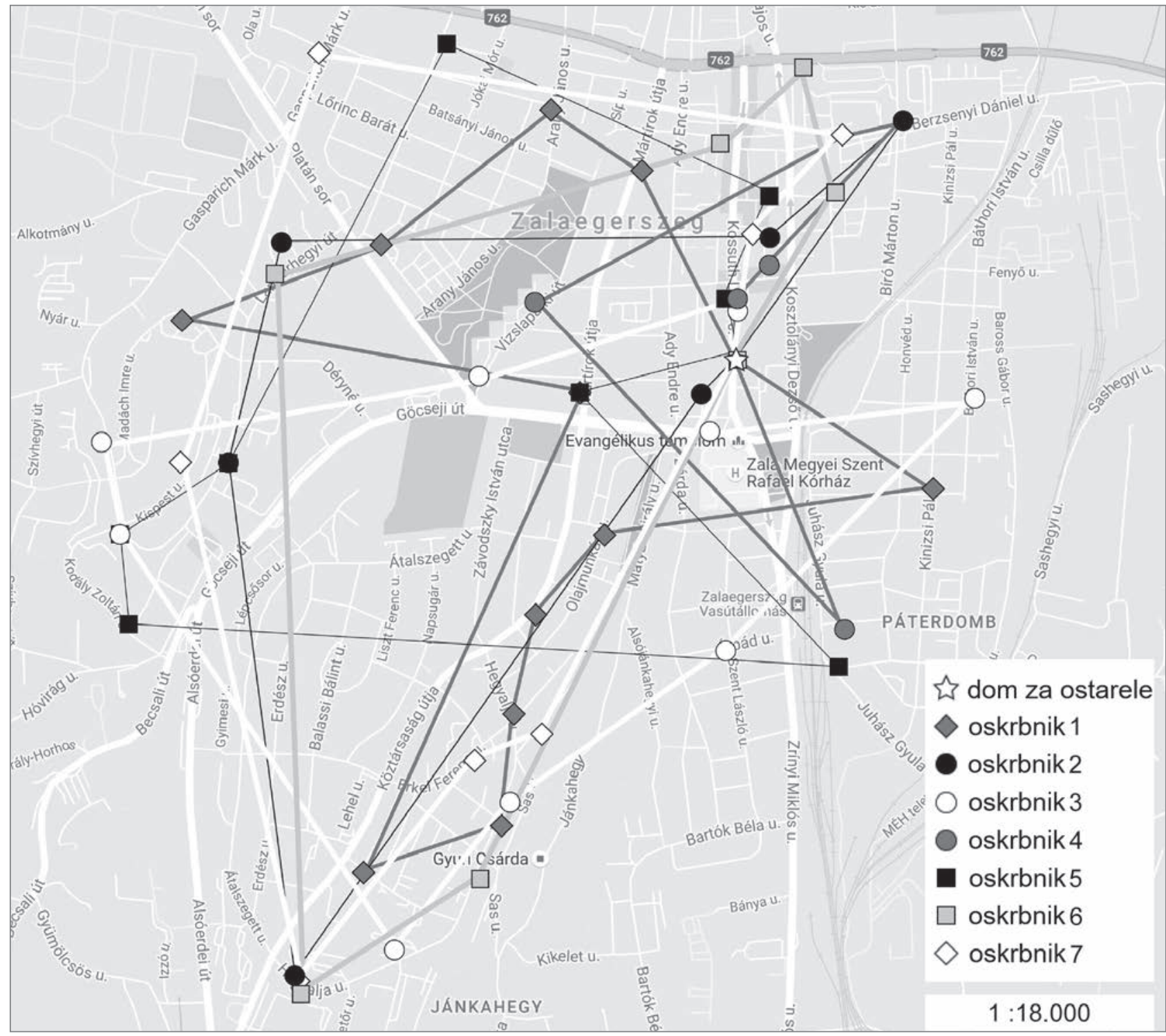

Slika 4: Scenarij načrtovanja 1.1, optimalna pot za 7 oskrbnikov

Preglednica 3: Izračuni in rezultati scenarija načrtovanja 1.1 in variacij za 2.1

\begin{tabular}{llllllll}
\hline Scenarij & $\sigma$ časa poti & Skupna razdalja & Skupni čas & Št. oskrbnikov & Povprečen čas & Čas optimizacije & Delež poti \\
\hline začetni & 1,811 & 210,9 & $2.724,9$ & 11 & 247,72 & & $7,73 \%$ \\
\hline 2.1 & 0,132 & 55 & 2.527 & 6 & 422,16 & 9,98 & $2,4 \%$ \\
\hline 2.1 & 0,905 & 107,75 & $2.765,75$ & 7 & 395,10 & 21,61 & $3,90 \%$ \\
\hline 1.1 & 1,811 & 219,8 & $2.804,8$ & 7 & 400,68 & 13,67 & $7,84 \%$ \\
\hline 2.1 & 3,623 & 445,2 & $2.950,2$ & 8 & 368,78 & 22,08 & $15,09 \%$ \\
\hline 2.1 & 5,435 & 654 & 3.194 & 8 & 399,25 & 5,8 & $20,48 \%$ \\
\hline 2.1 & 7,246 & 832,8 & $3.410,8$ & 9 & 378,98 & 7,56 & $24,42 \%$ \\
\hline 2.1 & 9,057 & $1.146,5$ & $3.813,5$ & 10 & 381,35 & 6,56 & $30,06 \%$ \\
\hline
\end{tabular}

V drugem scenariju smo predvideli povečano število starostnikov $/ \mathrm{km}^{2}$. Originalna matrica razdalj je bila prilagojena za manjše zahteve in je imela natančno enako standardno deviacijo kot primer $\mathrm{z}$ višjim številom starostnikov $\sigma=1,8115$. Da bi imeli višje število starostnikov in še vedno uporabili realne podatke, smo v scenarij vključili predpisani čas nege za starostnike, ki niso bili na urniku na najbolj zapolnjen dan. Pripomoček Microsoft Excel solver je za optimizacijo potreboval 13,66 minute. Kot je razvidno s slike 5 in preglednice 4, zahteva povečanje števila starostnikov več delovne sile, pri poti pa ni bilo pomembne razlike pri enaki razpršenosti. Število starostnikov se je povečalo za $21,8 \%$. To naj bi se glede na 


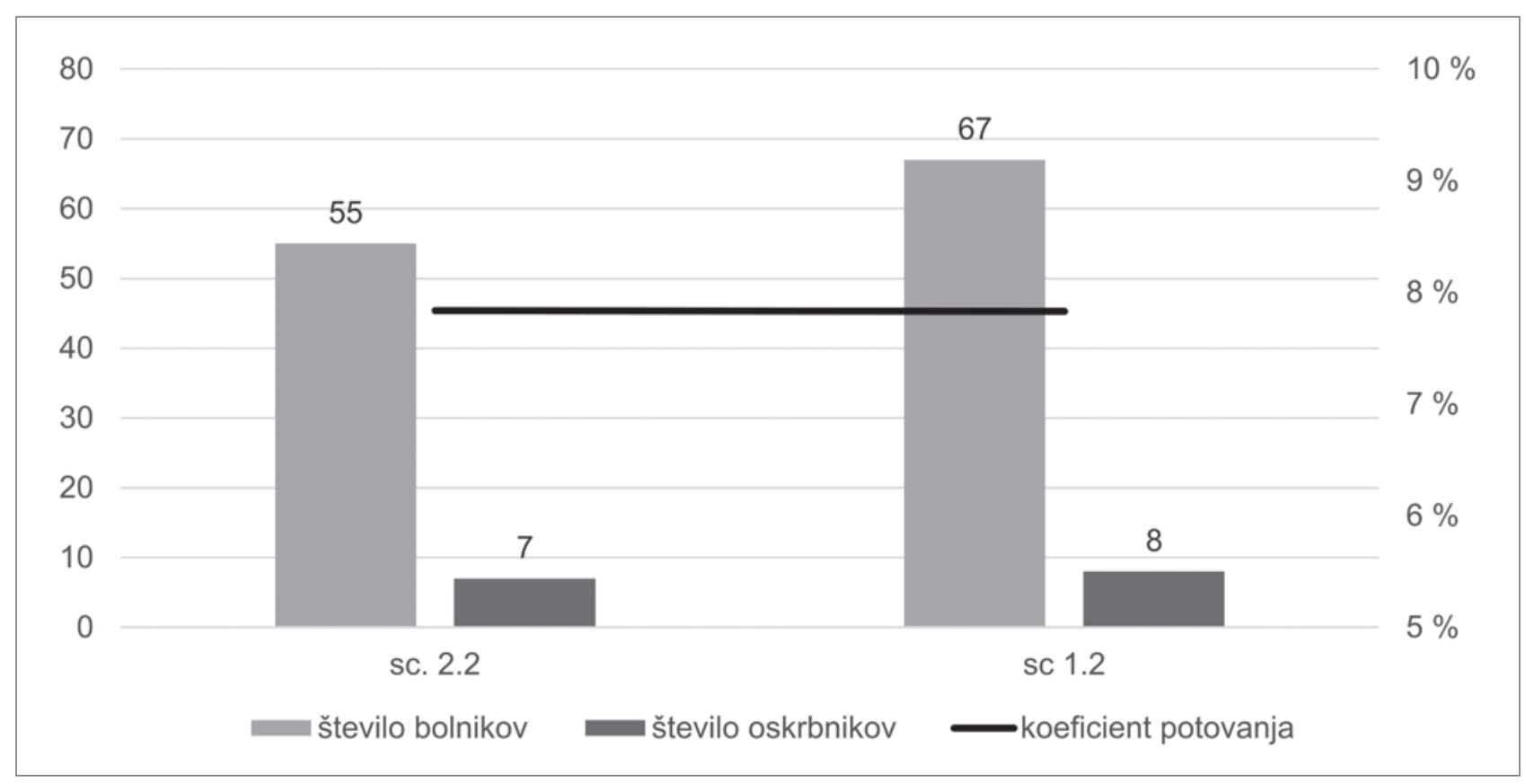

Slika 5: Dva scenarija z enakim deležem poti ter spreminjanjem števila starostnikov in sester

Preglednica 4: Izračuni in rezultati scenarija načrtovanja 1.2 in 2.

\begin{tabular}{lllllll}
\hline Scenarij & Št. starostnikov & Skupna razdalja & Skupni čas & Št. oskrbnikov & Povprečni čas & Delež poti \\
\hline 2.2 & 55 & 219,8 & $2.804,8$ & 7 & 400,685 & $7,836 \%$ \\
\hline 1.2 & 67 & 261,8 & $3.343,8$ & 8 & 417,975 & $7,829 \%$ \\
\hline
\end{tabular}

projekcije EUROSTAT (Evropska Komisija, 2015a) zgodilo do leta 2030. Z optimalnim načrtovanjem se je čas poti glede na skupni čas celo zmanjšal - za 0,007 \%.

\section{Razprava in sklepi}

Optimizacija načrtovanja poti za izvajalce oskrbe na domu, ki obiskujejo starostnike, lahko pomaga zmanjšati stroške (v našem primeru merjene $s$ časom in številom zaposlenih oskrbnikov), povezane z oskrbo na domu, vendar so ti odvisni tudi od prevoznih sredstev in razpršenosti bivališč starostnikov. $\mathrm{V}$ članku smo predstavili različne scenarije prostorske razpršenosti in gostote zahtev $\mathrm{v}$ mestu $\mathrm{z}$ uporabo podatkov o dejanskih lokacijah starostnikov in o predpisani negi. Z logističnega vidika so lahko načrtovalcu distribucijskega sistema v pomoč ocene zahtev in prostorske razpršenosti. V praksi sprememba ene spremenljivke običajno vpliva na drugo, tako da smo v naših raziskovalnih scenarijih skušali ločiti učinka teh dveh spremenljivk, da bi izmerili njun vpliv na opravljanje oskrbe na domu. Strokovna literatura o problemih oskrbe na domu namenja pozornost različnim vidikom načrtovanja poti in urnika, vendar ji primanjkujeta dve razlikovalni lastnosti: učinek različnih vzorcev razpršenosti stanovanjskih enot in izbira načina prevoza nista vključeni kot spremenljivki objektivne funkcije, temveč le kot predeterminirana vpliva njene cene. Z upošte- vanjem tega so nastali študijski scenariji. Z njimi smo ponazorili vlogo vzorcev rabe zemljišča pri omogočanju dolgotrajne oskrbe, torej pokazali na razmerje med izzivi demografskih sprememb in urbanim razvojem. Za optimizacijo načrtovanja poti smo uporabili generalizirani problem trgovskega potni$\mathrm{ka}$ (ang. multiple travelling salesman problem, mTSP). Namen optimizacije je bil zmanjšati število oskrbnikov pri dani omejitvi delovne obremenitve. Za predvidevanje sprememb smo uporabili dva scenarija: enega, pri katerem gre za območje z manjšo razpršenostjo stanovanj (večstanovanjske zgradbe), in drugega, pri katerem gre za soseske, kjer so bivališčca bolj razpršena (enodružinske hiše) in predmestja. Ugotovili smo, da ima prostorska razporeditev lokacij, ki jih je treba obiskati, pomemben vpliv na čas, porabljen za pot, in na skupni čas, potreben, da se opravi nega na domu. Čas poti se sorazmerno povečuje s spremembo standardne deviacije razdalje med bivališči starostnikov.

V zaključku raziskave smo ponovno proučili prvi scenarij, vendar s fiksno prostorsko razpršitvijo, in spremenili le število lokacij. Ugotovili smo, da število starostnikov ne vpliva bistveno na čas, ki ga zahteva nega. Da bi razporedili vse starostnike, smo morali dodati še enega oskrbnika, vendar se delež časa, porabljen za pot, ni pomembno spremenil (glede na skupni čas). Na sliki 6 so prikazani proučevani scenariji. Lahko vidimo, da je vpliv večjega števila starostnikov majhen glede na delež časa 


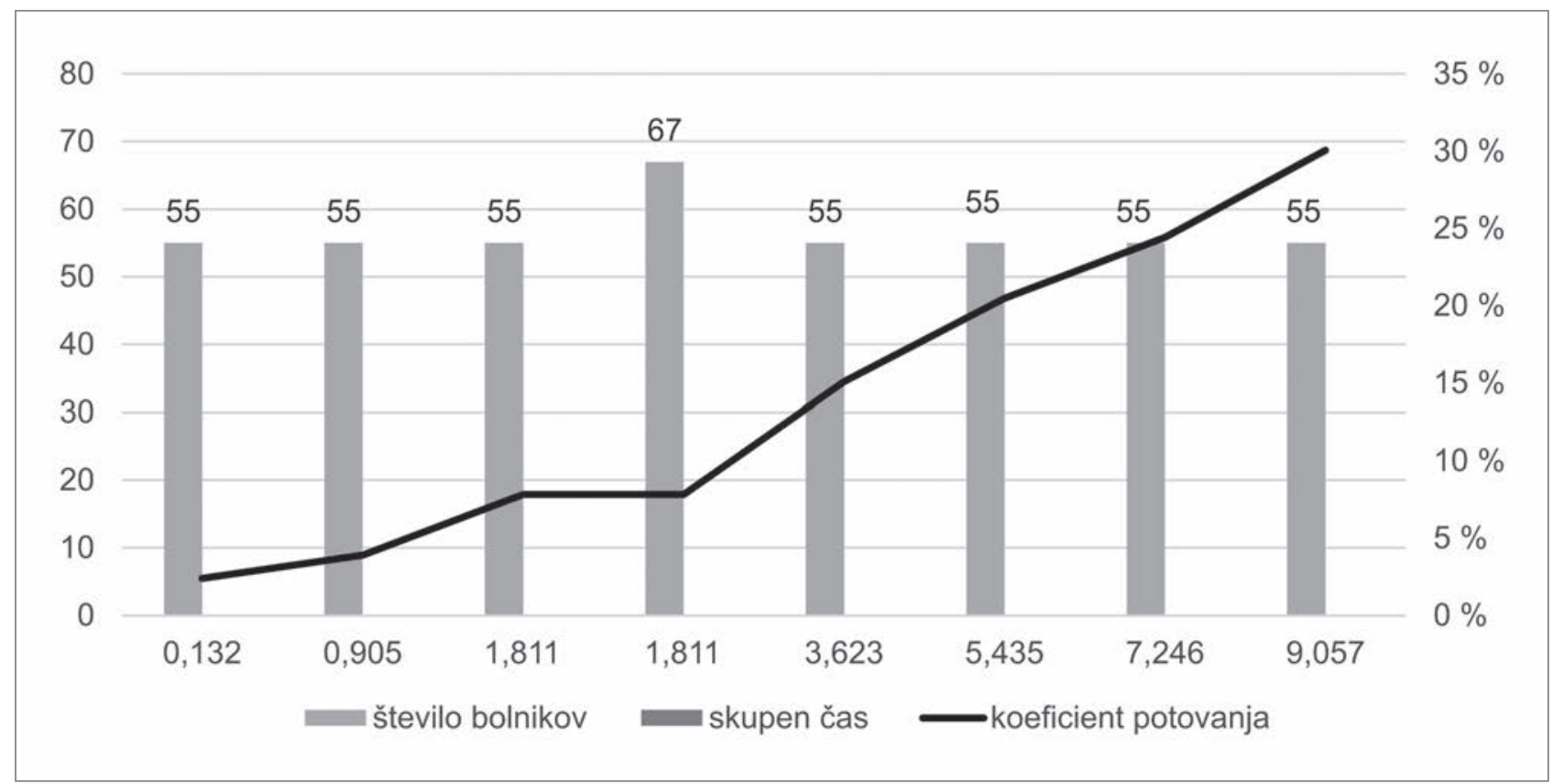

Slika 6: Proučevani scenariji gostote zahtev in razpršitve glede na razmerje časa poti

poti, prostorska razpršenost (merjena kot standardna deviacija, $\sigma)$ pa postopno povečuje čas poti, do $30 \% \mathrm{v}$ zadnjem proučevanem primeru. Zaposlitev dodatnega oskrbnika je bila nujna, saj se je predpisan čas nege povečal za do štiri ure na dan. Tega obsega ni mogoče naložiti drugim oskrbnikom, vendar je takšna praksa malo verjetna, saj morajo starostniki, ki potrebujejo okoli štiri ure dnevne nege, razmisliti tudi o drugih možnostih, kot je nega na domu. V raziskavi smo želeli ohraniti rešitev, izvedljivo v trenutnih razmerah.

Glede na rezultate simulacije je treba osvetliti logistične aspekte dolgotrajne oskrbe na domu za ponudnike teh storitev. $\mathrm{Na}$ splošno ni mogoče vplivati na število zahtev starostnikov zaradi staranja populacije, zato je treba razmisliti o spremenljivkah, ki jih lahko vsaj delno nadzorujemo. Na prostorsko razpršenost je mogoče vplivati $z$ načrtovanjem urbanega okolja in prostorskimi načrti, zato poudarjamo pomen upoštevanja teh podatkov. Ker so $\sigma$ potovalnega časa poti pomembno vplivale na potrebe po delovni sili, kot prikazuje ta študija, je lahko ta ukrep uporaben za izbiro transportnih sredstev in odločitve o lokaciji objektov. Prostorskim načrtovalcem je lahko v pomoč, da predvidijo rezultate razvojnih odločitev v urbanem okolju, bodisi ko gre za boljše infrastrukturne povezave za kolesarje ali javni transport bodisi ko gre za izbiro lokacije za nove stanovanjske enote.

\section{Norina Szander}

MEDIFAS, Mediteranski inštitut za sodobne študije, Vrtojba, Slovenija in Fakulteta za organizacijske študije v Novem mestu, Novo mesto, Slovenija

E-pošta: norina.szander@medifas.net
Lorenzo Brian Ros-McDonnell

Business engineering research group, Universidad Politécnica Cartagena, Cartagena, Španija in MEDIFAS, Mediteranski inštitut za sodobne študije, Vrtojba, Slovenija

E-pošta: lorenzo.ros@upct.es

\section{Marija Bogataj}

MEDIFAS, Mediteranski inštitut za sodobne študije, Vrtojba, Slovenija in Fakulteta za organizacijske študije v Novem mestu, Novo mesto, Slovenija

E-pošta: marija.bogataj@guest.arnes.si

\section{Viri in literatura}

Bektas, T. (2006): The multiple traveling salesman problem: an overview of formulations and solution procedures. Omega, 34(3), str. 209-219. DOI: 10.1016/j.omega.2004.10.004

Briggs, R. (2010): Descriptive statistics for spatial distributions - review; Dostopno na: http://www.utdallas.edu/ briggs/ (sneto 12. 6. 2016).

Centralna madžarska statistična pisarna (2016): Real property of the municipalities. Dostopno na: http://www.ksh.hu/docs/hun/xstadat/ xstadat_eves/i_zri001b.html (sneto 20. 3. 2017).

Chopra, S. (2003): Designing the distribution network in a supply chain. Transportation Research Part E: Logistics and Transportation Review, 39(2), str. 123-140. DOI: 10.1016/S1366-5545(02)00044-3

Csehák, J. (2003): Retirement homes or elderly homes? Dostopno na: http://www.parlament.hu/irom37/3957/3957-001.htm (sneto 20. 3. 2017).

Czibere, K., in Gál, R. I. (2010): The long-term care system for the elderly in Hungary (978-94-6138-021-0). Dostopno na: http://www.ancien-longtermcare.eu/node/27 (sneto 12. 6. 2016).

Statistični urad pri Evropski komisiji (2016): Population density. Dostopno na: http://ec.europa.eu/eurostat/web/products-datasets/-/tps00003 (sneto 12. 6. 2016). 
Evropska komisija (2015a): The 2015 ageing report - Economic and budgetary projections for the 28 EU Member States (2013-2060). Dostopno na: http://ec.europa.eu/economy_finance/publications/ (sneto 12. 6. 2016).

Evropska komisija (2015b): Innovation for active \& healthy ageing. Final report. Dostopno na: ec.europa.eu/ageing-summit-2015 (sneto 12. 6. 2016).

Gillsjö, C., Schwartz-Barcott, D., in von Post, I. (2011): Home: The place the older adult can not imagine living without. BMC Geriatrics, 11(1), str. 1-10. DOI: 10.1186/1471-2318-11-10.

Golant, S. M. (2002): Deciding where to live: The emerging residential settlement patterns of retired Americans. Generations, 26(2), str. 66.

Kavšek, M., in Bogataj, D. (2015): Smernice kakovosti dolgotrajne oskrbe. V: Ros McDonnell, L., Bogataj, D., in Kavšek, M. (ur.): Dolgotrajna oskrba: izzivi in priložnosti: oskrbovalni in bivalni vidiki, str. 1-27. Šempeter pri Gorici, MEDIFAS in Ljubljana, Skupnost socialnih zavodov Slovenije.

Kavšek, M., in Bogataj, D. (2016): Ageing in Place Driving Urban Transformations. Journal of Universal Excellence, 5(1), str. 1.

Keenan, T. A. (2010): Home and community preferences of the $45+$ population. Dostopno na: http://assets.aarp.org/rgcenter/general/ home-community-services-10.pdf (sneto 12. 6. 2016).

Kučera, T., in Burcin, B. (2010): Changing age structure of population as a challenge for local authorities: Population prospects for city district Prague 3. V: Kovács, Z. (ur.): Challenges of Ageing in Villages and Cities: The Central European Experience, str. 132-160. Szeged, Department of Economic and Social Geography, University of Szeged.

Miller, C. E., Tucker, A. W., in Zemlin, R. A. (1960): Integer programming formulation of traveling salesman problems. Journal of the ACM (JACM), 7(4), str. 326-329. DOI: 10.1145/321043.321046

OECD (2015): Ageing in cities. Paris, OECD Publishing.

Rosta, A., Zimborás, B., Mészáros, Á. in Kovács, S. (2014): Social map of Zalaegerszeg. Zalaegerszeg, Zalaegerszeg Municipality.

Svet Evropske unije (2014): Priporočilo Sveta z dne 8. julija 2014 v zvezi z nacionalnim programom reform Slovenije za leto 2014 in mnenje Sveta o programu Slovenije za stabilnost za leto 2014 (2014/C 247/22). Dostopno na: http://ec.europa.eu/europe2020/pdf/csr2014/ csr2014_council_slovenia_en.pdf (sneto 20. 3. 2017).

Szander, N., Ros-McDonnell, L., in Bogataj, M. (2016): A feasible nurse routing plan for the elderly: Quality and spatial trade-offs. V: C. Jaca in M. Sainz (ur.): Building bridges between researchers and practitioners. San Sebastian: Tecnun - University of Navarra, Industrial Management Department.

Szirmai, V., Váradi, Z., Kovács, S., in Schuchmann, J. (2010): The issue of ageing in large Hungarian urban regions. V: Z. Kovács (ur.): Challenges of ageing in villages and cities: The Central European experience, str. 161177. Szeged, Department of economic and social geography, University of Szeged. 